\title{
PROGRAM PENGELOLAAN PESISIR DAN PPK KEGIATAN DED PENINGKATAN STATUS PPI PULAU BAAI PROVINSI BENGKULU
}

As ad

\begin{abstract}
With the increase in PPI development Changes in social interactions that will be experienced by the people of Sumber Jaya Village occur because of fish traders who come from outside the village or even from outside the city of Bengkulu who come to PPI Baai Island to buy fish from collectors. In addition, changes in social interactions that occur in the midst of the community of Sumber Jaya Sub-District are a conflict between residents of Sumber Jaya Village and Andon fishermen who come from out of town and even outside the island. While in terms of economy, these changes will be seen from the amount of labor absorption that occurs around the location of the Baai Island PPI in the city of Bengkulu.

The coastal community around PPP Pulau Baai is optimistic that it will experience a change towards the good with the increase in Baai Island PPI. Because the community of Sumber Jaya sub-district itself will feel there is a change in the area that used to be quiet now becomes more crowded. In addition, according to the Sumber Jaya village community itself who works as a fisherman, an increase in the development of the Baai Island PPI is expected to facilitate fishermen in carrying out activities before or after going to sea compared to the development of Baai Island PPI where fishermen had to spend more energy. With the development and improvement of the status of Baai Island PPI the number of people from outside the coastal area of Sumber Jaya Sub-District who came both in the purpose of buying and selling as well as andon fishermen would influence the social interaction of the surrounding coastal communities. In this case the change will lead to positive and negative aspects.
\end{abstract}

Keywords: Development, Social and Economic Policy

C2019 Universitas Prof. Dr. Hazairin, SH.

\section{LATAR BELAKANG}

1. Setiap pembangunan yang dilakukan hendaknya dapat terarah dengan baik sesuai dengan kebutuhan agar pembangunan yang dilakukan tidak sia-sia dan bermanfaat serta memudahkan penggunanya bila telah selesai pembangunannya. Oleh sebab itu setiap pembangunan diperlukan Perencanaan yang matang agar tidak menimbulkan masalah, baik itu secara sosial maupun ekonomi, dikemudian hari dan masih dapat dikembangkan bila masih diperlukan.

2. Kegiatan DED Peningkatan Status PPI Pulau Baai harus dilakukan oleh pemberi jasa Perencanaan yang kompeten, dan dilakukan secara penuh dengan menempatkan tenagatenaga ahli Perencana sesuai kebutuhan dan kompleksitas pekerjaan.

3. Konsultan Perencana bertujuan secara umum merencanakan Kegiatan Perencanaan DED Peningkatan Status PPI Pulau Baai yang rapi dan teratur agar dapat efektif dan efisien sehingga dapat dipergunakan secara maksimal bila hasil pekerjaan tersebut telah selesai di bangun.

As'ad ( $\square)$

Fakultas Ekonomi Universitas Prof. Dr. Hazairin, SH.

Email : asadamirhasan@yahoo.co.id 
As ad, Program Pengelolaan Pesisir dan PPK Kegiatan DED Peningkatan Status PPI Pulau Baai Provinsi Bengkulu

4. Kerangka acuan Kerja (KAK) untuk pekerjaan Perencanaan perlu di siapkan secara matang sehingga mampu mendorong perwujudan karya Perencanaan yang sesuai dengan kepentingan proyek.

\section{RUMUSAN MASALAH}

Dari uraian latar belakang di atas, maka dapat dibuat rumusan masalah sebagai berikut :

1. Bagaimana kebijakan pembangunan PPI Pulau Baai Bengkulu

2. Bagaimana dampak kehidupan social masyarakat pesisir sekitar dan

3. Bagaimana dampak kehidupan ekonomi masyarakat pesisir sekitar.

\section{RUANG LINGKUP PENELITIAN}

Dalam penelitian ini, peneliti memberikan batasan fokus penelitian sebagai berikut :

1. Kebijakan Pembangunan PPI pulau Baai Bengkulu,

2. Dampak kehidupan Sosial Masyarakat Pesisir sekitar, dan

3. Dampak Kehidupan Ekonomi Masyarakat pesisir sekitar.

Lokasi penelitian ini adalah Pelabuhan Perikanan Ikan (PPI) Pulau Baai Kota Bengkulu, yang mana masyarakat pesisir sekitar yang merasakan dampak adanya peningkatan PPI tersebut

Lokasi Pekerjaan Perencanaan DED Peningkatan Status PPI Pulau Baai terletak di Kawasan Komplek PPI Pulau Baai Provinsi Bengkulu

\section{TUJUAN PENELITIAN}

1. Kebijakan Pembangunan PPI pulau Baai Bengkulu,

2. Dampak kehidupan Sosial Masyarakat Pesisir sekitar, dan

3. Dampak Kehidupan Ekonomi Masyarakat pesisir sekitar

\section{TINJAUAN PUSTAKA}

\section{A. Pengertian Kebijakan Pembangunan}

Pengertian Kebijakan Pembangunan a. Kebijakan Kebijakan dalam Kamus Besar Bahasa Indonesia diartikan sebagai rangkaian konsep dan asas yang menjadi garis besar dan dasar rencana dalam pelaksanaan suatu pekerjaan, kepemimpinan, dan cara bertindak (tentang pemerintahan, organisasi, dan sebagainya); pernyataan citacita, tujuan, prinsip, atau maksud sebagai garis pedoman untuk manajemen dalam usaha mencapai sasaran; garis haluan.1 Kebijakan umumnya dianggap sebagai pedoman untuk bertindak atau saluran untuk berpikir. Secara lebih khusus kebijakan adalah pedoman untuk melaksanakan suatu tindakan. Kebijakan mengarahkan tindakan untuk mencapai sasaran atau tujuan. Kebijakan menjelaskan bagaimana cara pencapaian tujuan dengan menentukan petunjuk yang harus diikuti. Kebijakan ini dirancang untuk menjamin konsistensi tujuan dan untuk menghindari keputusan yang berwawasan sempit dan berdasarkan kelayakan.

Menurut Knoepfel dan kawan-kawan dalam buku Solichin Abdul Wahab berpendapat mengartikan kebijakan sebagai: "a series of decisions or activities resulting from structured and recurrent interactions between different actors, both public and private, who are involved in various diffrent ways in the emergence, indentification and resolution of a problem defined politically as a public one" (serangkaian keputusan atau tindakantindakan sebagai akibat dari interaksi terstruktur dan berulang di antara berbagai aktor yang terlibat berbagai cara dalam merespons, mengidentifikasikan, dan memecahkan suatu masalah yang secara politis didefinisikan sebagai masalah publik). 
Versi formal yang dibuat oleh Perserikatan Bangsa-Bangsa (PBB) dalam buku Solichin Abdul Wahab, agaknya lebih luas dan cukup rinci ketimbang pandangan di atas, karena lembaga dunia ini telah memberikan makna pada kebijakan sebagai berikut:

"Kebijakan ialah pedoman untuk bertindak. Pedoman itu bisa saja amat sederhana atau kompleks, bersifat umum atau khusus, luas atau sempit, kabur atau jelas, longgar atau terperinci, bersifat kualitatif atau kuantitatif, publik atau privat. Kebijakan dalam maknanya seperti ini mungkin berupa suatu deklarasi mengenai suatu dasar pedoman bertindak, suatu arah tindakan tertentu, suatu program mengenai aktivitas-aktivitas tertentu, atau suatu rencana"

Berdasarkan beberapa pengertian kebijakan tersebut, maka penulis memahami arti dari kebijakan sebagai sebuah rangkaian rencana atau keputusan untuk kemudian dijadikan acuan tindakan yang dimanifestasikan dalam bentuk program-program terkait persoalan tertentu dalam rangka mencapai tujuan yang diinginkan. Jadi kebijakan sangat penting perannya sebagai pemandu dalam menentukan arah tindakan yang harus dipatuhi dan dilakukan secara konsisten dalam mencapai tujuan atau sasaran yang telah ditetapkan.

Pembangunan merupakan suatu proses transformasi yang dalam perjalanan waktu ditandai oleh perubahan struktural, yaitu perubahan pada landasan kegiatan ekonomi maupun pada kerangka susunan ekonomi masyarakat yang bersangkutan.

Adapaun inti mengenai pembangunan menurut Prof. Denis Goulet minimal ada tiga komponen dasar atau tata nilai yang seharusnya menjadi dasar konsepsi dan panduan praktis agar benar-benar bisa memahami arti pembangunan. Tiga tata nilai yang dimaksud itu yakni, pertama yang berkaitan dengan nafkah hidup. Dalam hal ini bahwa setiap orang mempunyai kebutuhan hidup yang pokok seperti pangan, papan, kesehatan, dan perlindungan. Kedua, harga diri menjadi orang. Dalam hal ini dinilai bahwa kehidupan yang baik adalah sikap yang bisa menghargai diri sendiri. Sikap percaya dan hormat terhadap diri sendiri tidak digunakan sebagai alat dari tujuan-tujuannya. Ketiga, sasaran pembangunan.

Singkatnya pembangunan merupakan suatu kenyataan fisik dan suatu keadaan jiwa yang diupayakan cara-caranya oleh masyarakat melalui kombinasi berbagai proses sosial, ekonomi, dan kelembagaan untuk mencapai kehidupan yang lebih baik.

Setelah uraian pengertian dari kebijakan dan pembangunan yang dikemukakan tersebut maka menurut hemat penulis bahwa yang dimaksud dengan kebijakan pembangunan adalah garis haluan yang menjadi dasar dalam pelaksanaan kegiatan di bidang pembangunan dengan target-target tertentu demi terwujudnya perubahan ke arah yang lebih baik. Perubahan yang dimaksud tentu mengindikasikan kehidupan yang lebih baik dengan tercapainya kesejahteraan melalui perbaikan kualitas/taraf hidup masyarakat.

Penetapan kebijakan pembangunan berpedoman kepada peraturan-peraturan yang telah ditetapkan pemerintah yaitu berdasarkan Undang-undang Nomor 25 Tahun 2004 tentang Sistem Perencanaan Pembangunan Nasional pasal 1 angka 3 dan Peraturan Menteri Dalam Negeri Nomor 54 Tahun 2010 tentang Pelaksanaan Peraturan Pemerintah Nomor 8 Tahun 2008 tentang Tahapan, Tatacara Penyusunan, Pengendalian, dan Evaluasi Pelaksanaan Rencana Pembangunan Daerah pasal 76, merupakan satu kesatuan tata cara perencanaan pembangunan untuk menghasilkan rencana-rencana pembangunan dalam jangka panjang, jangka menengah dan tahunan yang dilaksanakan oleh unsur penyelenggara negara dan masyarakat di tingkat pusat dan daerah.

\section{B. Tujuan Pembangunan}

Setiap bangsa membutuhkan pembangunan; ini merupakan suatu tujuan yang bagi kebanyakan orang merupakan hal yang wajar yang terjadi dengan sendirinya. Sementara kemajuan di bidang ekonomi merupakan unsur paling penting dari setiap pembangunan, 
namun unsur itu bukanlah satu-satunya. Ini disebabkan karena pembangunan tidak sematamata suatu fenomena ekonomi. Pada akhirnya, pembangunan menuntut kita memusatkan perhatian pada hal-hal yang lebih daripada sekedar sisi material dan finansial dari kehidupan manusia.

Usaha-usaha pembangunan yang sedang giat dilaksanakan oleh negara-negara sedang berkembang (developing countries) di dunia pada umumnya berorientasi kepada bagaimana memperbaiki atau mengangkat tingkat hidup (level of living) masyarakat di negara-negara tersebut agar mereka bisa hidup seperti masyarakat di negara-negara maju (developed countries).

Pembangunan ekonomi merupakan salah satu jawaban yang seakanakan menjadi semacam kunci keberhasilan bagi suatu negara untuk meningkatkan taraf hidup (levels of living) warga negaranya. Oleh sebab itu pembahasan-pembahasan masalah pembangunan banyak menaruh perhatian yang lebih besar pada nasib yang dihadapi oleh sebagian besar atau $2 / 3$ penduduk dunia yang berada di negara-negara sedang berkembang.

Pada pidato pengukuhannya sebagai Guru Besar dalam ilmu ekonomi dan studi pembangunan di Fakultas Ekonomi Universitas Airlangga, Surabaya, Suroso Imam Zadjuli dalam buku M. Arie Mooduto menegaskan tentang makna pembangunan.

"Sebagai penjabaran dari makna pembangunan dalam analisis secara praktis, pembangunan pada dasarnya dapat diartikan sebagai pertumbuhan terpimpin yaitu pertumbuhan yang dilaksanakan secara ekonomis dan efisien atau pertumbuhan sejalan dengan pertumbuhanpertumbuhan yang diinginkan dalam hal sikap masyarakat, kelembagaan, keadaan produksi dan tingkat kehidupan masyarakat. Biasanya pembangunan diartikan sebagai pertumbuhan dengan perubahan sosial. Namun pembangunan dapat diartikan pula sebagai pengaturan terhadap gerakan pertumbuhan melalui suatu sistem perencanaan pembangunan. Dengan kata lain, pembangunan adalah pertumbuhan terencana, dimana pertumbuhan tersebut direncanakan untuk memaksimumkan tingkat kemakmuran masyarakat sekarang maupun yang akan datang". Oleh karena itu, melalui pembangunan yang mengandung makna, terjadinya gerakan pertumbuhan melalui suatu sistem perencanaan pembangunan yang merupakan pertumbuhan terencana dalam memaksimumkan tingkat kemakmuran masyarakat di masa kini maupun masa yang akan datang, diyakini dapat mewujudkan ,kehidupan yang serba lebih baik ${ }^{e e}$.

Kehidupan yang serba lebih baik dimaksud, mengandung ,tiga tujuan intie yakni:

1. Peningkatan ketersediaan serta perluasan distribusi berbagai macam barang kebutuhan hidup yang pokok13, seperti pangan, sandang, papan, pendidikan, kesehatan, dan perlindungan keamanan.

2. Peningkatan standar hidup, tidak hanya berupa peningkatan pendapatan, tetapi juga meliputi penambahan penyediaan lapangan kerja, perbaikan kualitas pendidikan, serta peningkatan perhatian atas nilai-nilai kultural dan kemanusiaan yang kesemuanya itu tidak hanya untuk memperbaiki kesejahteraan materil, melainkan juga menumbuhkan jati diri pribadi dan bangsa yang bersangkutan.

3. Perluasan pilihan-pilihan ekonomis dan sosial bagi setiap individu dan bangsa secara keseluruhan, yakni dengan membebaskan mereka dari belitan sikap menghamba dan ketergantungan, bukan hanya terhadap orang atau negara-negara lain, namun juga terhadap setiap kekuatan yang berpotensi merendahkan nilai-niai kemanusiaan mereka.

Atas dasar pemikiran yang semacam inilah antara lain telah menimbulkan keyakinan, bahwa melalui ,pembangunan dapat diwujudkan „kehidupan yang serba lebih baik ${ }^{\text {ee }}$ sekaligus peningkatan ,,peningkatan kemakmuran masyarakat.

\section{Dampak Sosial, ekonomi Masyarakat}


Teori perubahan sosial sebagai awal mula munculnya teori tentang dampak sosial dan ekonomi. Sebelum membahas dampak sosial perubahan sosial sendiri diartikan oleh Wiryohandoyo (2002:1) sebagai suatu bentuk peradaban manusia akibat adanya perubahan alam, biologis, fisik yang terjadi sepanjang kehidupan manusia. Selain itu perubahan sosial yang terjadi menurut Kingslay Davis (dalm Djazifah, 2012:5) merupakan perubahanperubahan yang terjadi dalam struktur dan fungsi masyarakat. Pendapat lain dinyatakan oleh Selo Soemardjan (dalam Wulansari, 2009:126) bahwa perubahan sosial sebagai segala perubahan-perubahan pada lembaga-lembaga kemasyarakatan dalam suatu masyarakat yang mempengaruhi sistem sosialnya termasuk didalamnya nilai-nilai, sikap-sikap, dan pola-pola perilaku diantara kelompok-kelompok dalam masyarakat.

Dari penjelasan tentang perubahan sosial, dapat dijelaskan pertama tentang dampak sosial menurut Surto Haryono (dalam Dwi, 2015:21), dampak dibagi menjadi dua yaitu dampak primer dan dampak sekunder. Dampak primer adalah dampak yang langsung dirasakan oleh suatu kegiatan. Sedangkan lebih jelasnya Douglas dkk (dalam Disbudpar Banten, 2013:28) menjelaskan tentang analisis kebijakan dengan beberapa indikator seperti, (1) perubahan sistem sosial, (2) nilai-nilai individu dan kolektif, (3) perilaku hubungan sosial, (4) gaya hidup dan ekspresi mode serta, (5) struktur masyarakat. Sedangkan Fardani (2012:6) menyatakan bahwa dampak sosial adalah sebuah bentuk akibat atau pengaruh yang terjadi karena adanya sesuatu hal. Pengaruh yang dimaksud adalah akibat yang terjadi pada masyarakat, baik karena suatu kejadian itu mempengaruhi masyarakat atau hal lainnya didalam masyarakat.

Perubahan sosial yang tejadi di masyarakat juga menimbulkan dampak secara ekonomi, dampak ekonomi dijelaskan oleh Stynes (dalam Disbudpar Banten, 2013 : 20) dikelompokkan dalam tiga indikator, (1) direct effect meliputi penjualan, kesempatan kerja, pendapatan pajak, dan tingkat pendapatan, (2) indirect effect, meliputi perubahan tingkat harga, perubahan mutu dan jumlah barang dan jasa,perubahan dalam penyediaan properti dan variasi pajak, serta perubahan sosial dan lingkungan, (3) induced effects, yaitu pengeluaran rumah tangga, dan peningkatan pendapatan. Selain itu dampak ekonomi juga dijelaskan oleh Cohen (dalam Dwi, 2015 : 21) terdiri dari, (1) dampak terhadap pendapatan, (2) dampak terhadap aktivitas ekonomi, (3) dampak terhadap pengeluaran. Dari sini lebih diperjelas bahwa dampak ekonomi dijelaskan sebagai akibat dari suatu perubahan yang terjadi dilingkungan. Hal lain menurut Sinaga (dalam Setyaningsih, 2014: 6) dampak sosial ekonomi dapat dilihat dari sisi positif dan negatif sehingga dapat lebih berimbang dalam memberikan penilaian.

Sosial mengandung arti segala sesuatu yang berhubungan dengan masyarakat, sementara itu ekonomi memiliki artian sebagai ilmu yang berhubungan dengan asas produksi, distribusi, pemakaian barang serta kekayaan. Sekilas Sosial dan Ekonomi seperti dua hal dan cabang ilmu yang berbeda, namun diantara keduanya sebenarnya terdapat kaitan yang erat. Salah satu kaitan yang erat tersebut adalah, Jika keperluan ekonomi tidak terpenuhi maka akan terdapat dampak sosial yang terjadi di masyarakat kita.

Jadi bisa dijadikan kesimpulan adalah bahwa sosial ekonomi mengandung pengertian sebagai segala sesuatu hal yang berhubungan dengan tindakan ekonomi dalam pemenuhan kebutuhan masyarakat seperti sandang, pangan dan papan.

\section{METODE PENELITIAN}

\section{A. Jenis Penelitian}

Jenis penelitian yang digunakan di dalam penelitian ini adalah jenis penelitian kualitatif dengan pendekatan deskriptif.

\section{B. Jenis dan Sumber Data}


As ad, Program Pengelolaan Pesisir dan PPK Kegiatan DED Peningkatan Status PPI Pulau Baai Provinsi Bengkulu

Jenis data yang digunakan pada penelitian ini adalah jenis data kualitatif dan Kuantitatif, Data-data tersebut bersumber dari Dinas/instansi terkait serta sumber-sumber lain yang relevan dengan obyek yang diteliti.

\section{Populasi, Sampel dan Teknik Pengambilan Sampel}

Populasi penelitian adalah seluruh instansi terkait dan masyarakat pesisir yang ada di sekitar PPI Pulau Baai Bengkulu. Sedangkan sampelnya adalah DKP Propinsi Bengkulu dan masyarakat pesisir yang tinggal di sekitar PPI Pulau Baai sebanyak 50 orang. Teknik Pengambil sampel dilakukan secara Purpossiv Sampling.

\section{Teknik Pengumpulan Data}

Teknik pengumpulan data yang digunakan dalam penelitian ini adalah observasi, wawancara, dan dokumentasi. Instrument penelitian ada peneliti sendiri, pedomanan wawancara, catatan lapangan, dokumentasi.

\section{E. Definisi Operasional}

a. Kebijakan Pembangunan yang dimaksud kegiatan peningkatan pembangunan PPI ke PPN pulau Baai Bengkulu.

b. Dampak kehidupan Sosial yang dimaksud adalah Perubahan prilaku dan budaya penduduk yang ada di wilayah pesisir.

c. Dampak Kehidupan Ekonomi yang dimaksud adalah Perubahan ekonomi penduduk yang ada diwilayah pesisir.

\section{F. Alat Analisis}

Analisis data menggunakan Model Miles dan Huberman yang dikutif oleh Sugiyono (2013, 337). Analisis model interaktif ini melalui 3 (tiga) tahap yakni pengumpulan data, reduksi data, dan penyajian data dan penarikan kesimpulan.

\section{HASIL PENELITIAN DAN PEMBAHASAN}

\section{A. HASIL PENELITIAN}

\section{a. Gambaran Umum Obyek Penelitian}

Kawasan Pesisir Kota Bengkulu, secara administrasi berada di bagian Kota Bengkulu yang terdiri dari 8 (delapan) kecamatan dengan luas 151,7 Km2. Letak Kota Bengkulu sendiri, secara geografis berada di pantai Barat Sumatera pada posisi $102^{\circ} 14^{\prime \prime}-102^{\circ} 22$ “Bujur Timur dan $03^{\circ} 45^{\prime}$ " $03^{\circ} 59$ "Lintang Selatan.

Wilayah laut kewenangan Kota Bengkulu adalah 4 mil laut (nautical mile) atau 7,4 km, yang merupakan bagian dari Samudera Indonesia. Dengan panjang garis pantai lebih kurang $35 \mathrm{~km}$. Morfologi dasar laut dicirikan dengan pola kontur garis kedalaman yang sejajar dengan garis pantai, dengan morofologi sekitar pantai agak curam dan seterusnya landai; hal ini dapat dilihat pula dari lebih rapatnya garis kontur kedalaman ke arah garis pantai jika dibandingkan ke arah tengah laut. Pada jarak 4 mil laut dari garis pantai, kedalaman laut berada di sekitar $20 \mathrm{~m}$ di bawah permukaan laut, dengan kecenderungan semakin dalam ke arah utara/barat laut (ke arah Kota Bengkulu).

Secara administratif, Kota Bengkulu mempunyai luas wilayah daratan sekitar 151,7 $\mathrm{km}^{2}$,ditambah 1 pulau dengan luas $2 \mathrm{Ha}$ dan lautan seluas $387,6 \mathrm{Km}^{2}$ yang terdiri dari 8 kecamatan dan 67 kelurahan, dengan batas administratif sebagai berikut :

- Sebelah Utara berbatasan dengan Kabupaten Bengkulu Tengah;

- Sebelah Selatan berbatasan dengan Kabupaten Seluma;

- Sebelah Timur berbatasan Kabupaten Bengkulu Tengah; 
- Sebelah Barat berbatasan Samudera Hindia.

Kedudukan PPI Pulau Baai dengan dasar pembentukan Peraturan Gubernur Bengkulu no 22 tahun 2008 bahwasannya Pelaksana Teknis Operasional dilaksanakan oleh Dinas Kelautan dan Perikanan Provinsi Bengkulu dengan Visi Mewujudkan Fungsi dan Peran

Pelabuhan Perikanan Dalam Mendukung / Menunjang Pembangunan Perikanan yang Berkelanjutan dan Misi Tersedianya fasilitas yang memadai dalam rangka mendukung kegiatan bisnis perikanan dari pasca produksi, produksi, pengolahan hingga pemasaran serta pelayanan kapal-kapal perikanan. Menjadikan salah satu sumber PAD pada sektor perikanan serta Optimalisasi pengawasan penangkapan dan pengendalian sumberdaya ikan.

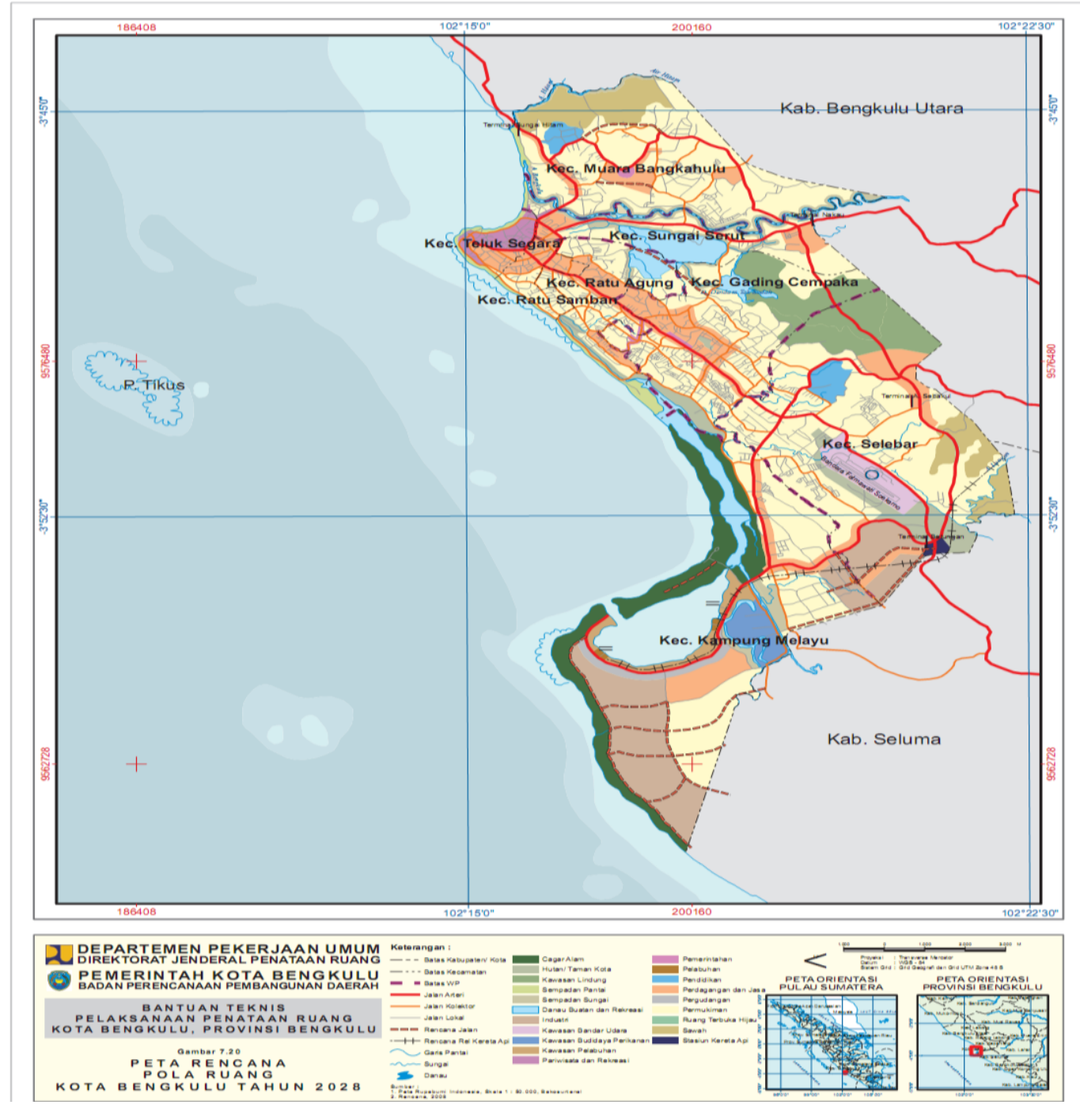

\section{b. Produksi Perikanan}

Sumberdaya perikanan tangkap di perairan laut Kota Bengkulu terdiri dari dua kategori, yaitu sumberdaya perikanan laut teritorial/pantai $(0-12$ mil laut) dan sumberdaya perikanan laut ZEEI (12 - 200 mil laut). Perairan laut teritorial memiliki potensi 46.145 ton/tahun, sedangkan perairan laut ZEEI memiliki potensi 80.072 ton/tahun. Potensi sumberdaya ikan yang terdapat di perairan laut Kota Bengkulu terdiri dari berbagai jenis ikan pelagis kecil, pelagis besar dan ikan demersal dan berbagai jenis udang. 
As ad, Program Pengelolaan Pesisir dan PPK Kegiatan DED Peningkatan Status PPI Pulau Baai Provinsi Bengkulu

Potensi sumberdaya perikanan laut Kota Bengkulu belum dapat dimanfaatkan secara optimal. Hal ini dapat dilihat dari perkembangan produksi perikanan tangkap yang masih rendah (perairan zona teritorial 12 mil laut). Terlihat bahwa tingkat pemanfaatan sumberdaya perikanan laut di Kota Bengkulu masih tergolong rendah dengan tingkat pemanfaatan rata-rata $25,51 \%$ pada perairan teritorial.

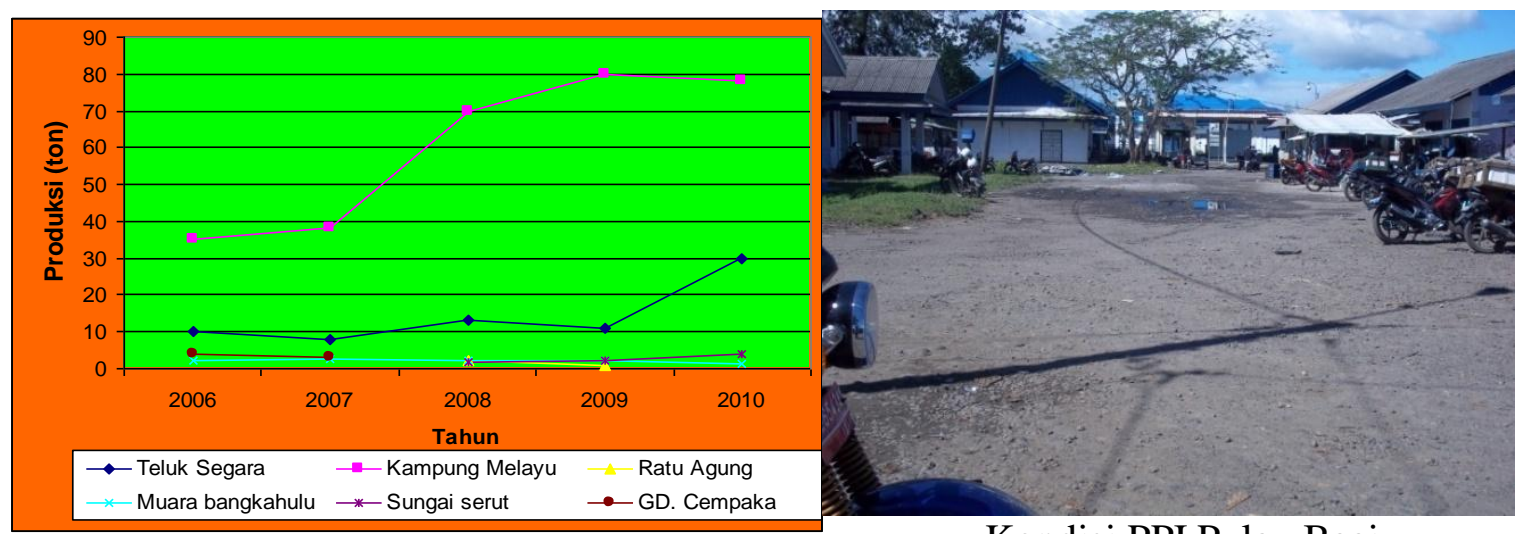

Grafik pemanfaatan sumberdaya perikanan

Kondisi PPI Pulau Baai

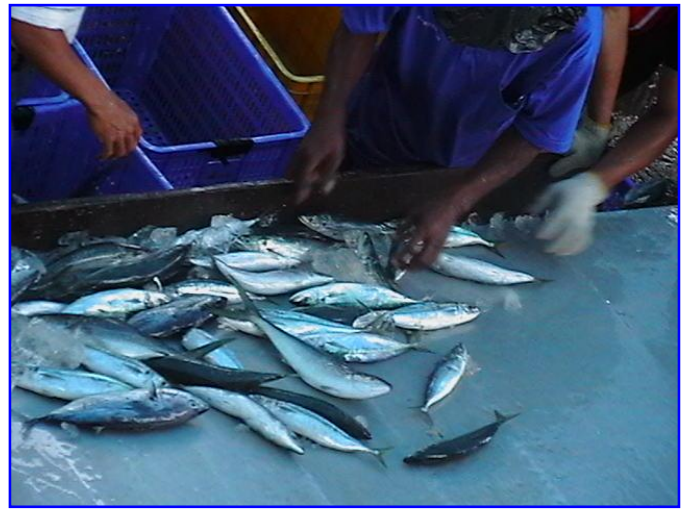

Produksi hasil tangkapan ikan yang didaratkan di PPI Pulau Baai Kota Bengkulu

Berdasarkan perkembangan produksi tiap bulannya di pendaratan ikan PPI Pulau Baai dan sekitarnya, menunjukkan bahwa terjadi peningkatan produksi mulai bulan Februari dan mencapai puncaknya pada bulan Oktober.

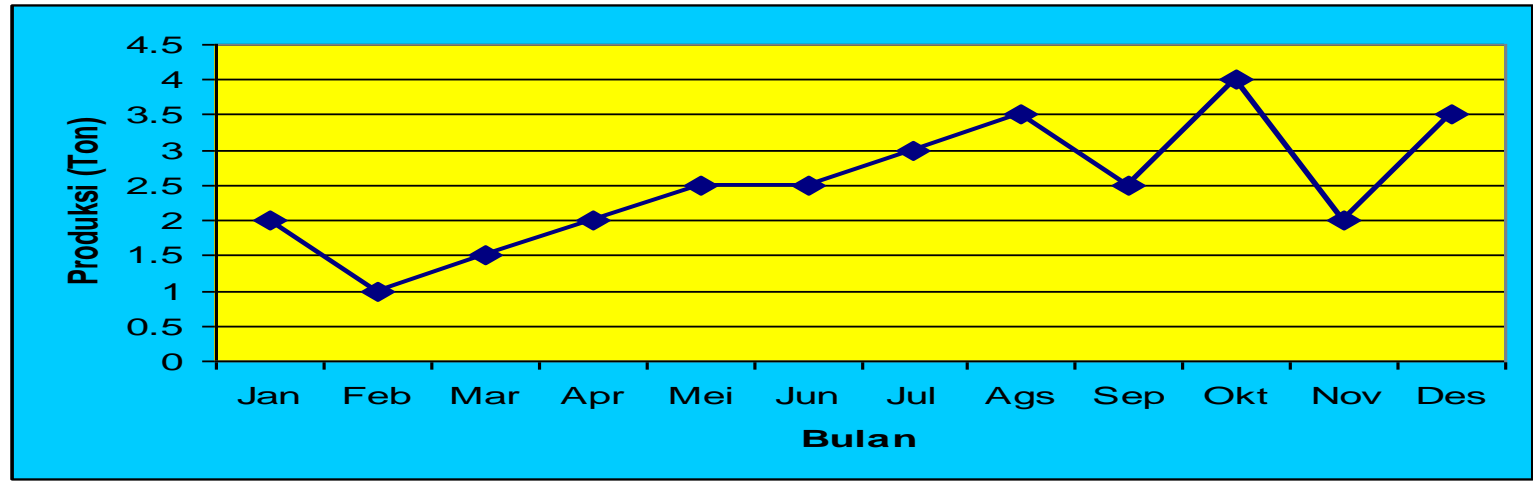

Potensi ikan pelagis yang cukup besar potensinya adalah ikan pelagis kecil dengan potensi sebesar 46.145 ton/tahun yang merupakan hasil tangkapan utama masyarakat 
nelayan, jenis yang tertangkap umumnya adalah jenis ikan tongkol, tenggiri, kembung, bawal, tetengkek, senangin, kerong, selar, dan kapas-kapas. Daerah penangkapan untuk jenis ikan pelagis kecil ini umumnya terdapat di perairan sepanjang pantai Kota Bengkulu, Seluma, Bengkulu Utara hingga sejauh 4 mil dari garis pantai.

Potensi perikanan lainnya yang cukup potensial adalah perikanan demersal. Jenis perikanan demersal yang biasa ditangkap nelayan adalah pari, kakap, kerapu, manyung, gulamah dan senangin.
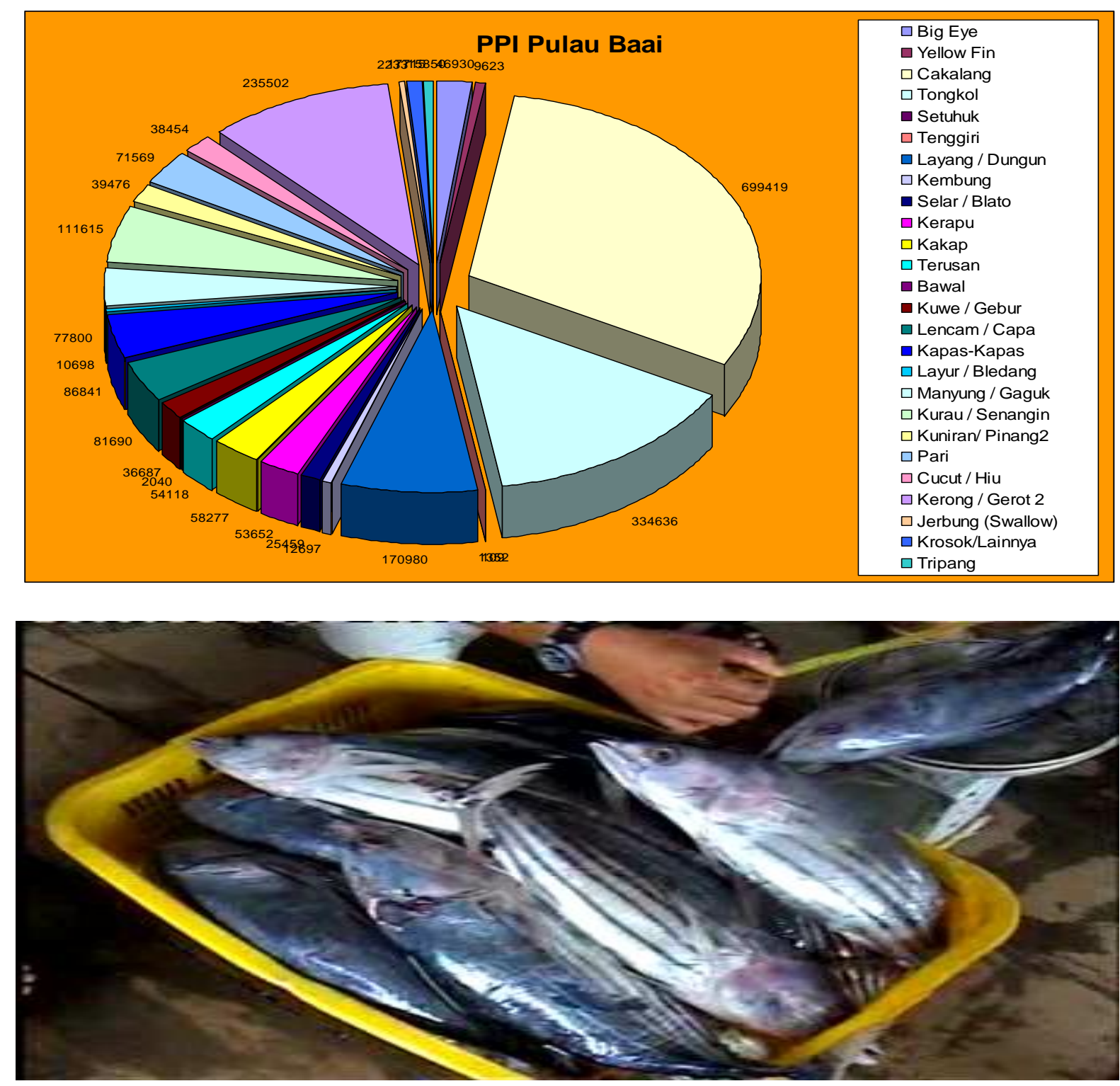

Produksi hasil tangkapan ikan nelayan menurut jenis ikan di PPI Pulu Baai

\section{c. Fungsi Lahan dan Pengembangan Lahan}

PPI Pulau Baai dimanfaatkan oleh masyarakat nelayan untuk mendukung dan memperlancar kegiatan usaha perikanan, tempat berlabuh dan pendaratan kapal perikanan, pusat penanganan dan pengolahan hasil perikanan serta pemasaran dan distribusi ikan hasil tangkapan, pusat pmbinaan, penyuluhan, dan pengumpulan data statistik, serta di manfaatkan juga sebagai pusat pengawasan pengelolaan SDI.

Lahan yang dimiliki PPI Pulau Baai, dengan kondisi lahan yang ada saat ini dirasakan kurang memadai apabila dilihat dari jumlah armada penangkapan yang semakin banyak dan 
berukuran besar serta volume pendaratan ikan yang makin besar sehingga perlu adanya perluasan lahan terutama untuk dermaga tambat labuh serta meningkatkan status pelabuhan menjadi Pelabuhan Perikanan Nusantara (PPN) atau Pelabuhan Perikanan Samudera (PPS). Apabila lahan yang ada di Pulau Baai tidak memungkinkan untuk dikembangkan lagi, maka perlu dicari alternatif lahan pelabuhan untuk meningkatkan status pelabuhan dan menampung armada perikanan yang berukuran besar.

Luas lahan dan bangunan PPI Pulau Baai Bengkulu

\begin{tabular}{|c|c|c|c|c|c|c|}
\hline \multirow[b]{2}{*}{$\begin{array}{l}\text { Nama } \\
\text { TPI/PPI }\end{array}$} & \multicolumn{6}{|c|}{ Kondisi Lahan dan Bangunan } \\
\hline & $\begin{array}{l}\text { S } \\
\text { lahan }\end{array}$ & $\begin{array}{l}\text { Luas } \\
\text { lahan } \\
\text { efektif }\end{array}$ & $\begin{array}{l}\text { Luas } \\
\text { Bangun } \\
\text { an (M2) }\end{array}$ & $\begin{array}{l}\text { Kondisi } \\
\text { Bangun } \\
\text { an }\end{array}$ & $\begin{array}{l}\text { Renca } \\
\text { na } \\
\text { penge } \\
\text { mbang } \\
\text { an } \\
\text { lahan }\end{array}$ & $\begin{array}{l}\text { Rencana } \\
\text { pengembangan } \\
\text { bangunan }\end{array}$ \\
\hline $\begin{array}{l}\text { PPI } \\
\text { Pulau } \\
\text { Baai }\end{array}$ & 50000 & 50000 & 38000 & Baik & & $\begin{array}{l}\text { - Pembuatan } \\
\text { bak } \\
\text { penampungan } \\
\text { air } \\
\text { - Docking } \\
\text { kapal } \\
\text { - Gudang ikan }\end{array}$ \\
\hline
\end{tabular}

\section{d. Sarana dan Prasarana Produksi}

Armada penangkapan ikan di laut terdiri dari tiga kategori, yaitu: perahu tanpa motor (PTM), dan kapal motor (KM). Untuk wilayah Kota Bengkulu, jumlah kapal motor terdiri dari berbagai ukuran mulai dari ukuran kurang dari 5 GT sampai ukuran lebih besar dari 100 GT. Perkembangan jumlah dari tiap jenis armada penangkapan ikan dapat dilihat pada Gambar dan masih di dominasi kapal motor ukuran 5 -10 GT.

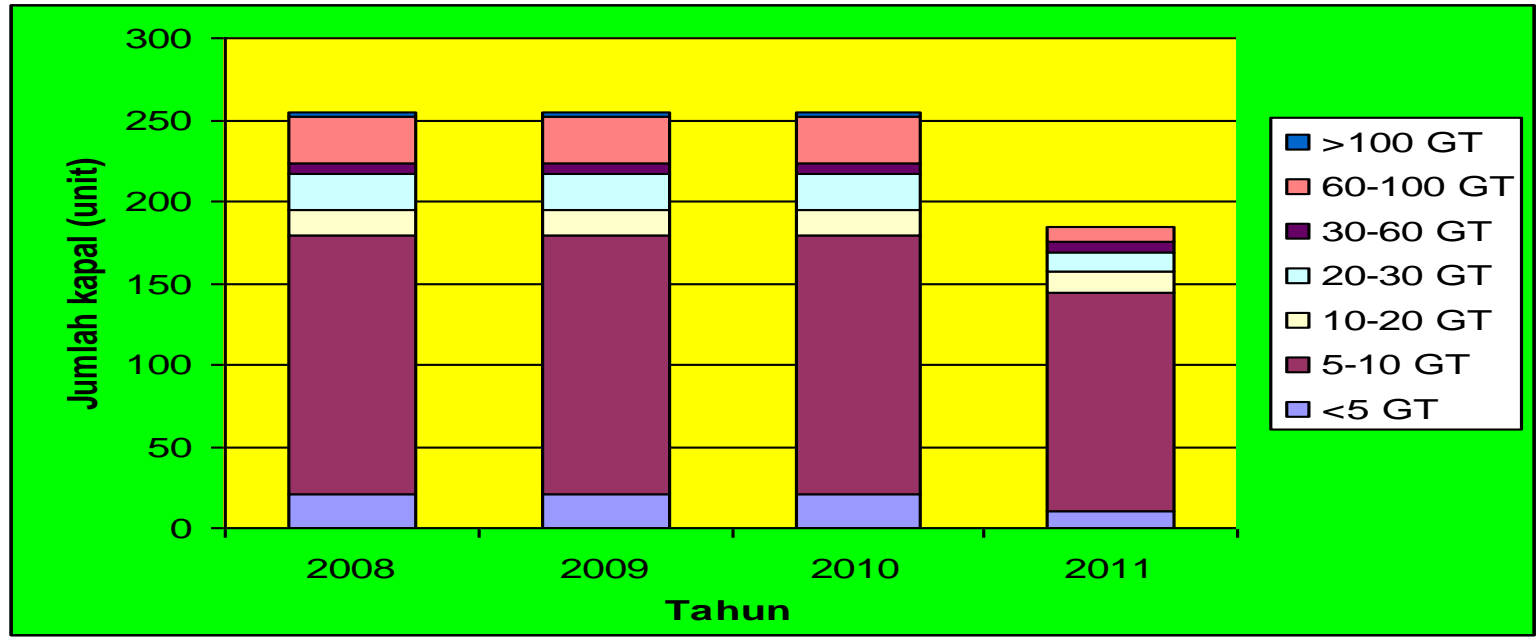


PARETO : Jurnal Ekonomi dan Kebijakan Publik

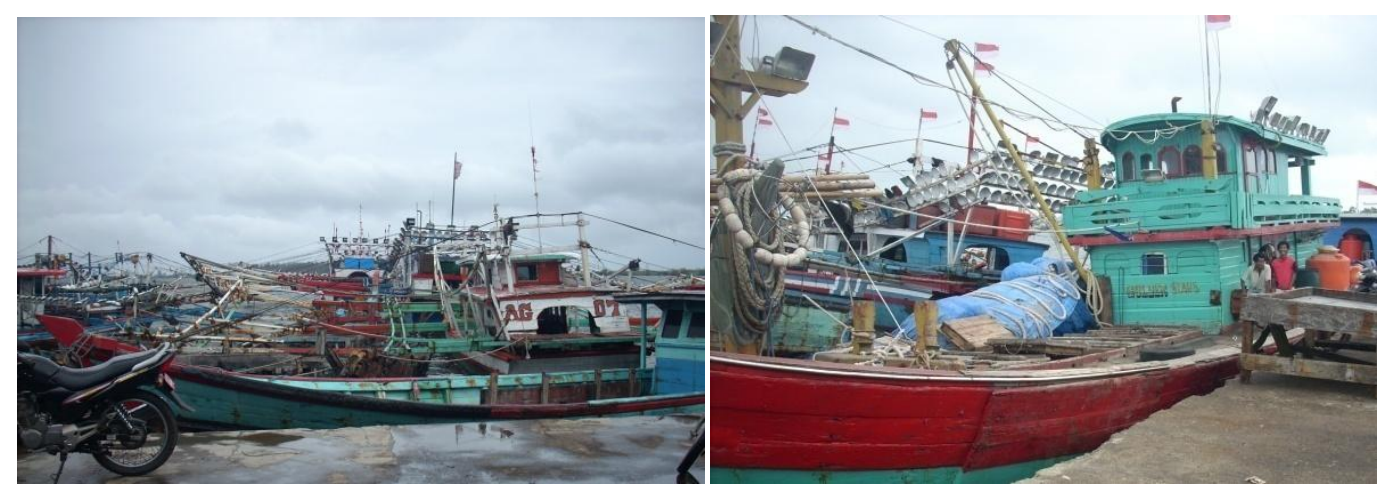

Perkembangan armada penangkapan ikan di Pulau Baai

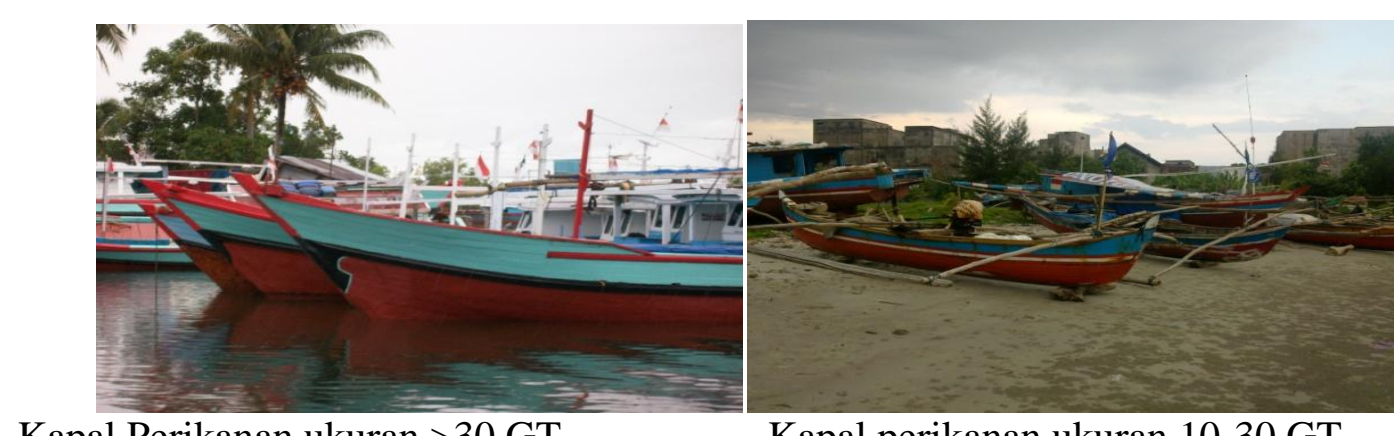

Kapal Perikanan ukuran >30 GT

Kapal perikanan ukuran 10-30 GT

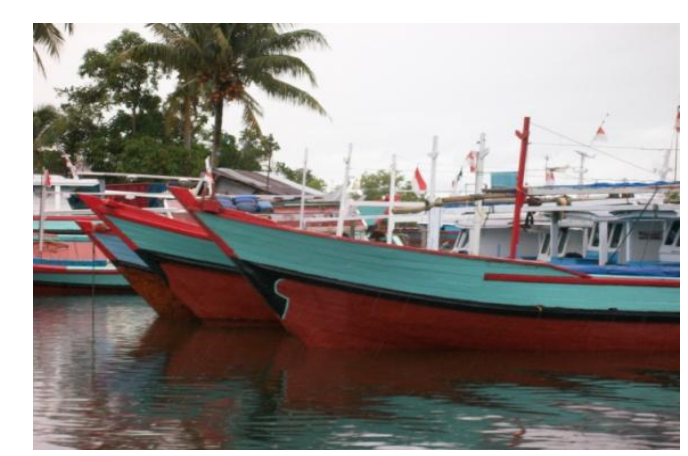

Kapal perikanan ukuran 5-10 GT Kapal perikanan ukuran <5GT

Aktivitas usaha pemanfaatan sumberdaya perikanan laut di Kota Bengkulu, dilakukan dengan berbagai jenis alat penangkapan ikan. Jenis alat penangkapan ikan yang digunakan oleh nelayan di Kota Bengkulu masih didominasi alat tangkap gill net dan hand line pada semua tempat pendaratan ikan. Jenis alat tangkap lainnya yang cukup banyak digunakan adalah alat tangkap purse seine dan bagan apung. 


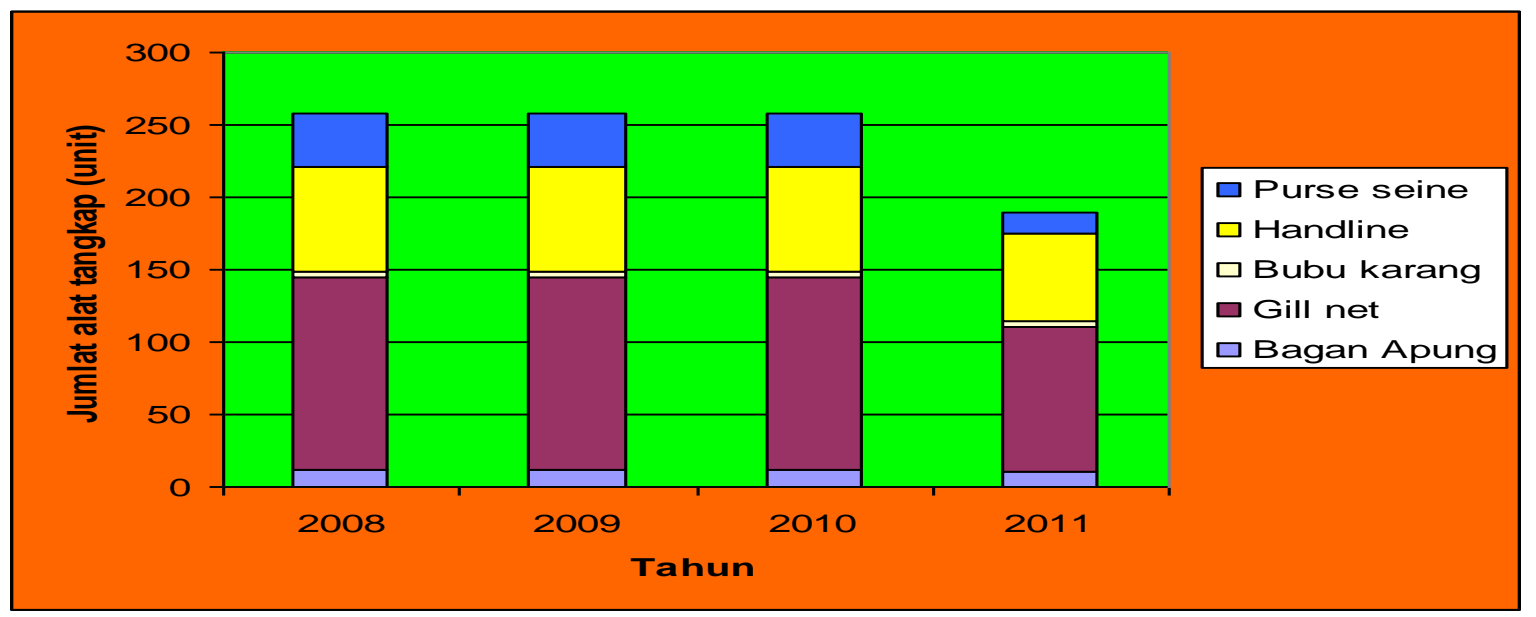

Gambar 4.8. Perkembangan alat penangkapan ikan di PPI Pulau Baai tahun 2008-2011

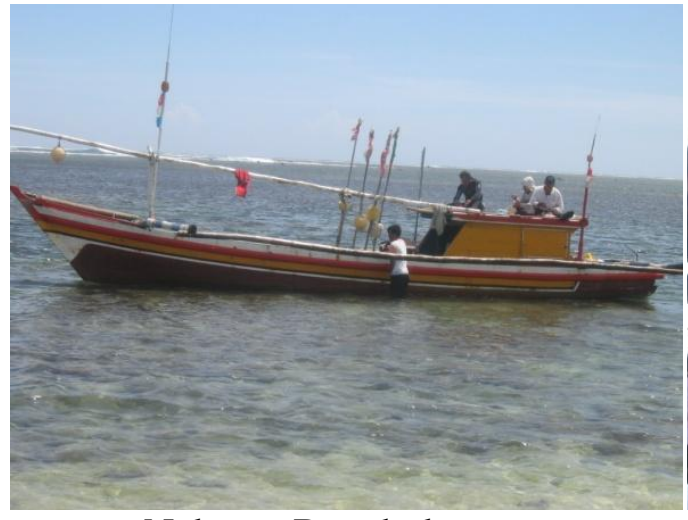

Nelayan Bengkulu

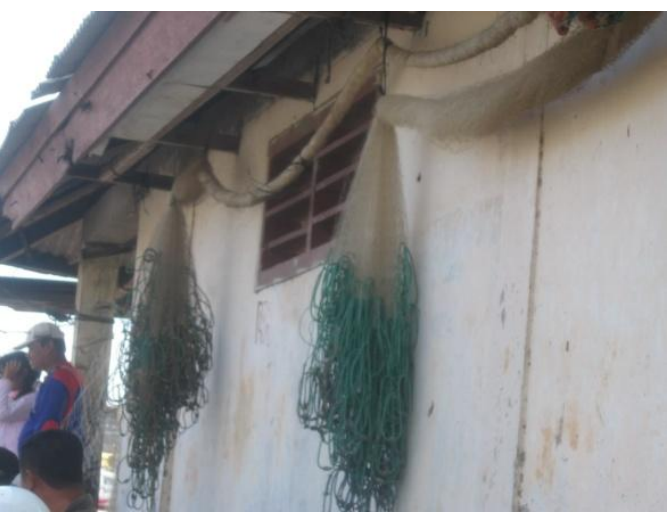

Alat tangkap jaring

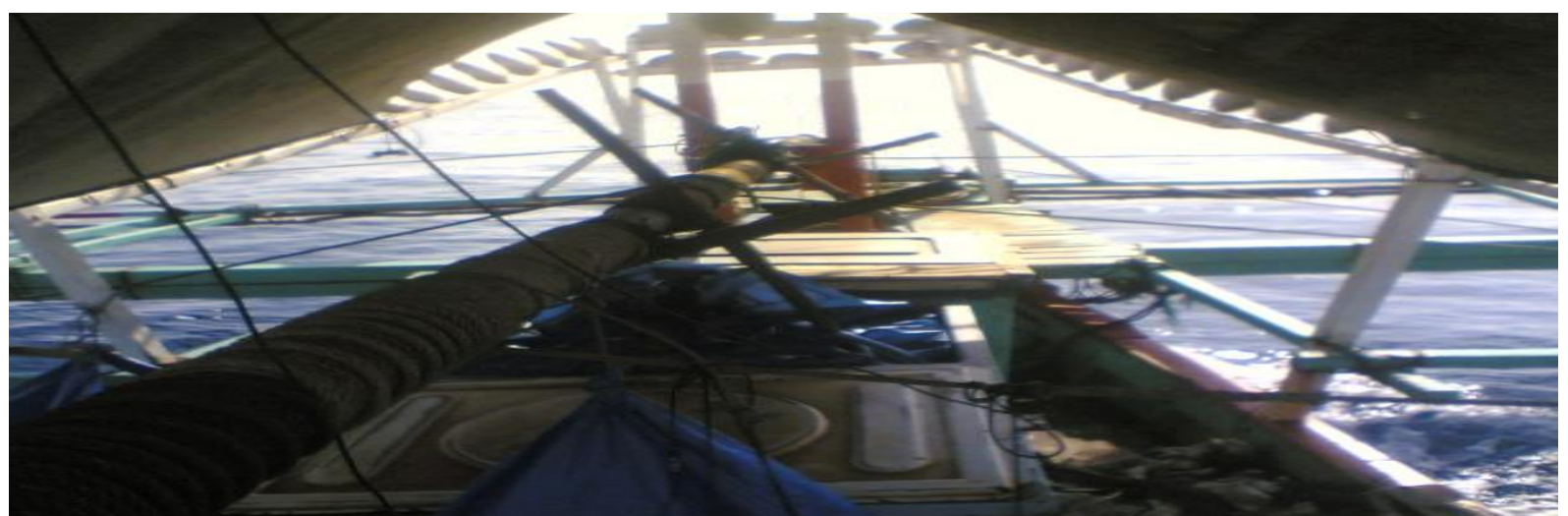

Alat tangkap bagan apung

\section{e. Sarana dan Prasarana Pengolahan dan Pemasaran}

Sarana dan prasarana pengolahan hasil perikanan belum tersedia di PPI Kota Bengkulu. Kegiatan pengolahan hasil perikanan yang dilakukan masih bersifat skala rumah tangga, jadi belum ada sarana dan prasarana yang disiapkan oleh pemerintah. Sedangkan saran dan prasarana pemasaran ikan terutama ikan segar sudah disiapkan pemerintah sehubungan dengan dibangunnya PPI Pulau Baai 
Sarana dan prasarana pengolahan dan pemasaran di PPI Kota Bengkulu

\begin{tabular}{|c|c|c|c|c|c|}
\hline No. & $\begin{array}{l}\text { Sarana dan } \\
\text { Prasarana }\end{array}$ & Lokasi & Spesifikasi & Jumlah & Kondisi \\
\hline 1 & Cold Storage & PPI P. Baai & & 2 & \\
\hline 2 & Cold box & & & & \\
\hline 3 & Fish container & PPI P. Baai & & 325 & \\
\hline 4 & Food processor & PPI P. Baai & & 1 & \\
\hline 5 & Gudang es & PPI P. Baai & $21 \mathrm{~m} 2$ & 1 & \\
\hline 6 & Gerobak dorong & PPI P. Baai & & 10 & \\
\hline 7 & Keranjang ikan & PPI P. Baai & & 154 & \\
\hline 8 & Kios ikan & & & & \\
\hline 9 & Pasar ikan & & & & \\
\hline 10 & Auning ikan & PPI P. Baai & & 3 & \\
\hline 11 & Penjemuran ikan & & & & \\
\hline 12 & Timbangan gantung & PPI P. Baai & & 1 & \\
\hline 13 & Mesin pemecah es & PPI P. Baai & & 2 & \\
\hline 14 & Gerobak dorong & PPI P. Baai & & 10 & \\
\hline 15 & Keranjang ikan & PPI P. Baai & & 154 & \\
\hline
\end{tabular}

Hasil penangkapan ikan yang mendarat di Pulau Baai Bengkulu dipasarkan dalam bentuk segar. Belum ada yang dipasarkan dalam bentuk hasil olahan, kecuali dalam bentuk pembekuan (pemberian es) namun masih dalam bentuk segar serta hanya sebagian kecil dalam bentuk ikan kering.

Tujuan daerah pemasaran lokal dalam Propinsi dan luar kota antara lain Medan, Bandung, Jakarta, Tanjung Balai dan keluar negeri yaitu ke Malaysia, Singapura, Hongkong dan Taiwan.

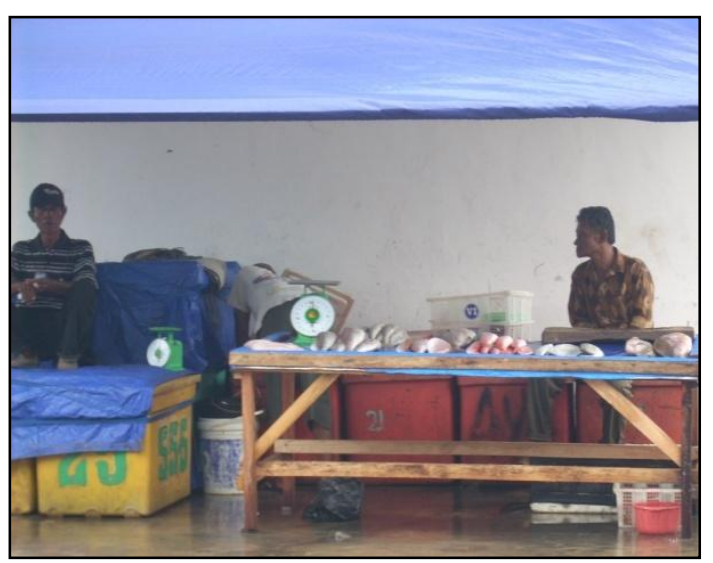

Auning ikan segar di PPI Pulau Baai

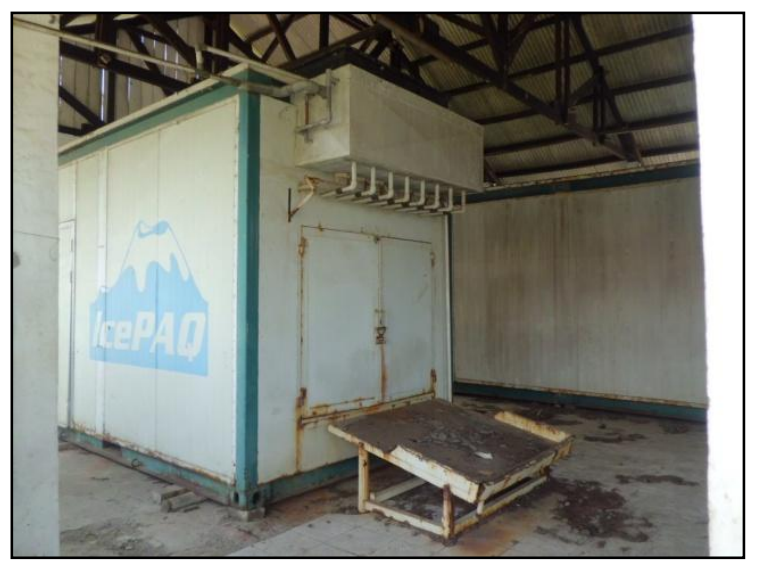

Cold Storage di PPI Pulau Baai

\section{f. Sarana dan Prasarana PPI}

Selama kurun waktu operasionalnya sampai sekarang, PPI Pulau Baai telah berfungsi baik. Segenap fasilitas yang ada telah difungsikan dan telah dimanfaatkan untuk menunjang aktivitas kapal melaut, pemasaran ikan, penanganan, pengolahan dan pembinaan mutu ikan, 
As ad, Program Pengelolaan Pesisir dan PPK Kegiatan DED Peningkatan Status PPI Pulau Baai Provinsi Bengkulu

pengumpulan data statistik perikanan, pengendalian dan pengawasan kapal ikan, penyampaian informasi perikanan kepada nelayan, pengembangan masyarakat nelayan, pengembangan wisata bahari, dan pembinaan masyarakat pantai. PPI Pulau baai tetap merupakan unit pelaksana teknis Dinas Kelautan dan Perikanan Provinsi Bengkulu.

Saat ini PPI Pulau Baai memiliki sarana pemasaran dan distribusi ikan berupa TPI dan pasar ikan dan areal industri untuk menampung kegiatan pengepakan dan pengolahan ikan. Kebutuhan fasilitas bagi PPI Pulau Baai disesuaikan dengan pola kegiatan operasional pelabuhan perikanan. Fasilitas pokok ini meliputi:

1. Dermaga sepanjang $400 \mathrm{~m}$, terdiri dari dermaga tambat kapal-kapal 5-20 GT sepanjang 50 m, kapal 20-30 GT sepanjang $50 \mathrm{~m}$ dan kapal 30 -100 GT sepanjang $100 \mathrm{~m}$. Dermaga bongkar ikan sepanjang $100 \mathrm{~m}$ dan dermaga servicing $100 \mathrm{~m}$.

2. Kolam 3,2 Ha dengan variasi kedalaman $-3 \mathrm{~m},-2,5 \mathrm{~m}$ dan $-2 \mathrm{~m}$.

3. Jaringan drainase dan Rambu navigasi.

Fasilitas fungsional yang berfungsi untuk memberikan pelayanan dan manfaat langsung yang diperlukan untuk kegiatan operasional suatu pelabuhan perikanan. Fasilitas fungsional ini terdiri dari:

1. Fasilitas pemasaran dan distribusi hasil perikanan: Tempat pelelangan ikan, gudang ikan .

2. Fasilitas perbekalan: tangki BBM 2 Unit dan tangki air.

3. Fasilitas pemeliharaan/perbaikan: gedung utility, tempat perbaikan jaring, dok/galangan kapal

4. Fasilitas pengolahan: cold storage, .Food proessing.

5. Kantor, Balai pertemuan nelayan, asrama nelayan, instalasi listrik, sarana komunikasi radio $\mathrm{SSB} /$ all band, telepon, internet, gardu jaga $\mathrm{WC}$ umum.

Sarana dan prasarana PPI di Kota Bengkulu

\begin{tabular}{|c|c|c|c|c|c|c|}
\hline \multirow[t]{2}{*}{ No. } & \multirow[t]{2}{*}{ Fasilitas } & \multirow[t]{2}{*}{ Satuan } & \multicolumn{2}{|c|}{ PPI Pondok Besi } & \multicolumn{2}{|c|}{ PPI Pulau Baai } \\
\hline & & & Volume & Kondisi & Volume & Kondisi \\
\hline A. & Fasilitas Pokok & & & & & \\
\hline \multirow[t]{9}{*}{1} & $\begin{array}{l}\text { Break water } \\
\text { (kiri) }\end{array}$ & $\mathrm{m}^{2}$ & & & & \\
\hline & $\begin{array}{l}\text { Break water } \\
\text { (kanan) }\end{array}$ & $\mathrm{m}^{2}$ & & & & \\
\hline & $\begin{array}{l}\text { Luas kolam } \\
\text { pelabuhan }\end{array}$ & $\mathrm{Ha}$ & & & 20,000 & \\
\hline & $\begin{array}{ll}\text { Panjang } & \text { alur } \\
\text { pelayaran } & \end{array}$ & $\mathrm{m}$ & & & & \\
\hline & $\begin{array}{ll}\text { Lebar } & \text { alur } \\
\text { pelayaran } & \end{array}$ & $\mathrm{m}$ & & & & \\
\hline & Panjang dermaga & $\mathrm{m}$ & & & 237 & \\
\hline & Drainase & $\mathrm{m}$ & & & 500 & \\
\hline & Jalan komplek & $\mathrm{m}$ & & & 650 & \\
\hline & Lampu navigasi & unit & & & & \\
\hline \multirow[t]{3}{*}{ B. } & $\begin{array}{l}\text { Fasilitas } \\
\text { fungsional }\end{array}$ & & & & & \\
\hline & Luas TPI & $\mathrm{m}^{2}$ & 300 & & 300 & \\
\hline & $\begin{array}{l}\text { Penampung air } \\
\text { bersih }\end{array}$ & $\mathrm{m}^{3}$ & 1000 & & 56 & \\
\hline
\end{tabular}


PARETO : Jurnal Ekonomi dan Kebijakan Publik

\begin{tabular}{|c|c|c|c|c|c|c|}
\hline & $\begin{array}{l}\text { Sumber air } \\
\text { bersih }\end{array}$ & Unit & 1 & Baik & 1 & $\begin{array}{l}\text { sumur } \\
\text { bor }\end{array}$ \\
\hline & $\begin{array}{l}\text { Jaringan air } \\
\text { bersih }\end{array}$ & $\mathrm{m}$ & $75 \mathrm{~m}$ & Baik & 360 & \\
\hline & $\begin{array}{l}\text { Kapasitas } \\
\text { Jaringan listrik }\end{array}$ & $\mathrm{KVa}$ & 300 & & & \\
\hline & $\begin{array}{ll}\text { Listrik } & \text { luar } \\
\text { gedung } & \end{array}$ & Unit & & & & \\
\hline & $\begin{array}{l}\text { Lampu penerang } \\
\text { jalan }\end{array}$ & Titik & 5 & Baik & & \\
\hline & Genset & $\mathrm{KVa}$ & 1500 & Baik & 1,500 & \\
\hline & Slipway & GT/unit & & & & \\
\hline & Bengkel & $\mathrm{m}^{2}$ & & & 70 & \\
\hline & $\begin{array}{l}\text { Ged. pertemuan } \\
\text { nelayan }\end{array}$ & $\mathrm{m}^{2}$ & & & 210 & \\
\hline & $\begin{array}{l}\text { Kantor } \\
\text { administrasi }\end{array}$ & $\mathrm{m}^{2}$ & 360 & Baik & 105 & \\
\hline & $\begin{array}{l}\text { Kantor } \\
\text { syahbandar }\end{array}$ & $\mathrm{m}^{2}$ & & & 60 & \\
\hline & $\begin{array}{l}\text { Menara } \\
\text { pengawas }\end{array}$ & unit & & & & \\
\hline & MCK & $\mathrm{m}^{2}$ & $8 \mathrm{~m}$ & Baik & 60 & \\
\hline & Area parkir & $\mathrm{m}^{2}$ & $500 \mathrm{~m}$ & Baik & 2,275 & \\
\hline & Rumah genset & $\mathrm{m}^{2}$ & & & & \\
\hline & Pagar & $\mathrm{m}$ & $200 \mathrm{~m}$ & & 780 & \\
\hline & Pos satpam & $\mathrm{m}^{2}$ & $12 \mathrm{~m}$ & & 4 & \\
\hline & SSB & Unit & & & 1 & \\
\hline & Tower & Unit & & & 1 & \\
\hline & SPDN & Unit & 1 & Rusak & 2 & \\
\hline & Kios BBM & Ton & & & & \\
\hline C. & $\begin{array}{l}\text { Fasilitas } \\
\text { Penunjang }\end{array}$ & & & & & \\
\hline & $\begin{array}{l}\text { Rumah Kepala } \\
\text { pelabuhan }\end{array}$ & $\mathrm{m}^{2}$ & & & 54 & \\
\hline & Rumah karyawan & $\mathrm{m}^{2}$ & 24 & Baik & 108 & type 36 \\
\hline & Guest House & unit & & & 4 & \\
\hline & Pos jaga & $\mathrm{m}^{2}$ & & & 4 & \\
\hline & Tempat ibadah & unit & & & 1 & \\
\hline & Telepon & unit & & & 1 & \\
\hline & Area industri & $\mathrm{m}^{2}$ & & & & \\
\hline
\end{tabular}




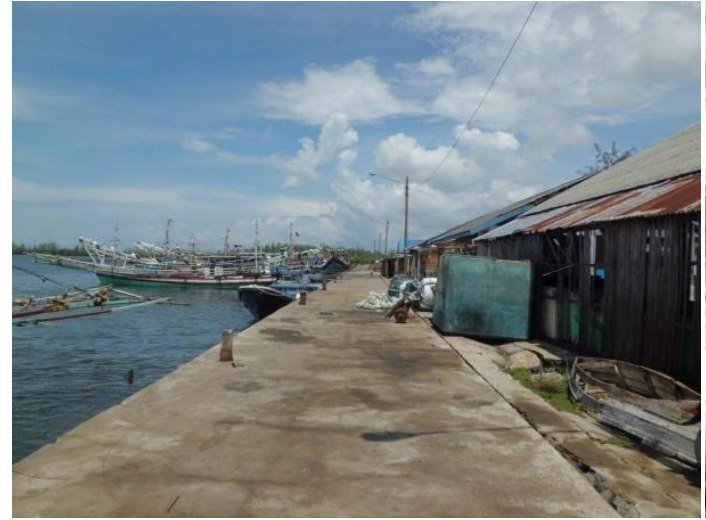

Dermaga PPI Pulau Baai

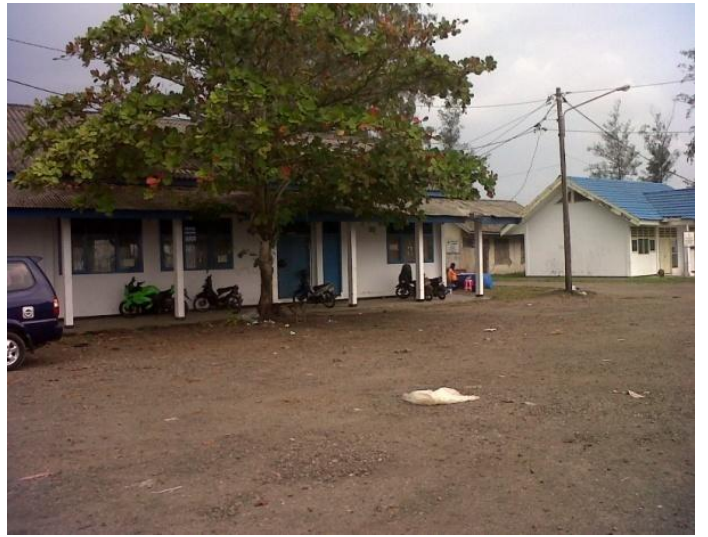

Gedung pertemuan nelayan di PPI Pulau Baai

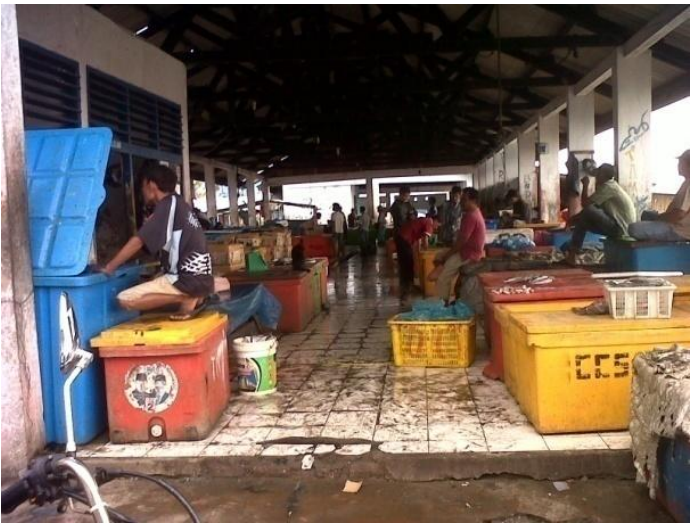

Tempat pelelangan di PPI Pulau Baai

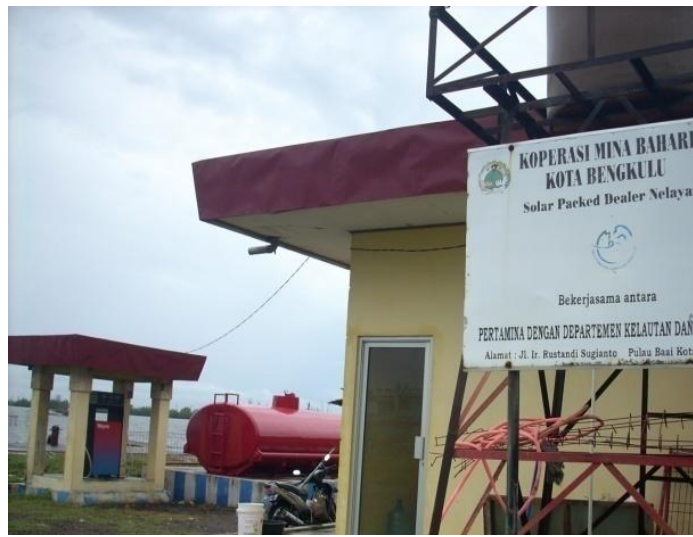

SPDN di PPI Pulau Baai

\section{g. Pengolah dan Pemasar Hasil Perikanan}

Saat ini di Propinsi Bengkulu telah tersedia beberapa pabrik es dan cold storage, namun kondisinya masih belum memadai untuk memenuhi kebutuhan perikanan di Bengkulu. Daftar perusahaan pengelola pabrik es dan cold storage dapat dilihat pada tabel berikut.

Kondisi pabrik es dan cold storage yang beroperasi di Kota Bengkulu

\begin{tabular}{|c|c|c|c|c|}
\hline No. & $\frac{\text { Nama }}{\text { Perusahaan }}$ & Lokasi & $\begin{array}{l}\text { Kapasitas } \\
\text { Produksi } \\
\text { (ton/hari) }\end{array}$ & Keterangan \\
\hline 1. & PT. AZ. BAGUS & Kota Bengkulu & 100 & Pabrik es \\
\hline 2. & CV. Jakarta & Kota Bengkulu & 80 & Pabrik es \\
\hline 3. & PT. Sari Salju & Kota Bengkulu & 25 & Pabrik es \\
\hline 4. & DKP Propinsi & Kota Bengkulu & 2 & $\begin{array}{l}\text { Pabrik es } \\
\text { mini }\end{array}$ \\
\hline 5. & PT. Mega Marin & Kota Bengkulu & 80 & Cold storage \\
\hline 6. & PT. AZ. BAGUS & Kota Bengkulu & 80 & Cold storage \\
\hline
\end{tabular}

Keberadaan produksi pabrik es yang ada selama ini baru untuk memenuhi kebutuhan nelayan di Kota Bengkulu, belum menjangkau kebutuhan nelayan di kabupaten. Kapasitas produksi pabrik es yang ada saat ini juga belum mampu memenuhi kebutuhan nelayan Kota Bengkulu sebagaimana diuraikan pada tabel berikut. 
Perkiraan kebutuhan es bagi nelayan di Kota Bengkulu

\begin{tabular}{lllllll} 
No. & Usaha Perikanan & $\begin{array}{l}\text { Trip } \\
\text { /bln }\end{array}$ & $\begin{array}{l}\text { Jumlah } \\
\text { Unit }\end{array}$ & $\begin{array}{l}\text { Kebutuhan } \\
\text { es/trip } \\
\text { (btg) }\end{array}$ & $\begin{array}{l}\text { Kebutuhan } \\
\text { es/bln } \\
\text { (ton) }\end{array}$ & $\begin{array}{l}\text { Rata/ } \\
\text { hari }\end{array}$ \\
\hline 1. & Pukat cincin & 3 & 24 & 500 & 1,800 & 60.00 \\
2. & Bagan & 25 & 25 & 20 & 625 & 20.83 \\
3. & Pancing & 3 & 40 & 100 & 600 & 20.00 \\
4. & Gill net (jaring hijau) & 10 & 45 & 100 & 2,250 & 75.00 \\
$\mathbf{5 .}$ & Lainnya & 25 & 75 & 10 & 938 & 31.25 \\
6. & Gudang skala kecil & 30 & 15 & 20 & 450 & 15.00 \\
$\mathbf{7 .}$ & Gudang skala besar & 30 & 7 & 100 & 1,050 & 35.00 \\
\hline & & Total & & $\mathbf{7 , 7 1 3}$ & $\mathbf{2 5 7 , 0 8}$ \\
\hline
\end{tabular}

Berdasarkan pada fakta di atas terlihat bahwa untuk memenuhi kebutuhan es bagi nelayan dan gudang pedagang di Kota Bengkulu saja dibutuhkan minimal 257 ton per hari. Sedangkan kapasitas produksi pabrik es yang ada saat ini sekitar 205 ton per hari, hal ini berarti terjadi kekurangan pasokan sebesar 52 ton per hari dan belum termasuk untuk kebutuhan non perikanan.

\section{h. Sumberdaya Manusia}

Salah satu faktor penentu keberhasilan pembangunan perikanan adalah ketersediaan sumberdaya manusia yang akan mengelola sumberdaya perikanan yang tersedia. Pengelolaan sumberdaya perikanan membutuhkan SDM untuk memanfaatkannya mulai dari penangkapan, pengolahan hingga pemasaran.

Balai Pelabuhan Khusus Perikanan Pulau Baai Bengkulu sesuai dengan tugas dan fungsinya dengan jumlah Personil 21 (dua puluh tiga) orang, yang terdiri dari 19 (Sembilan Belas) PNS dan 4 (empat) orang tenaga Honorer, dan 5 (lima) orang tenaga Fungsional.

Jumlah populasi tenaga kerja perikanan di Kawasan Pelabuhan Perikanan Pulau Baai, Kota Bengkulu meningkat cukup memadai. Hal ini disebabkan karena adanya peningkatan nelayan andon, dan menurut data dan informasi yang diperoleh pada saat survai menunjukkan bahwa jumlah nelayan andon pada tahun 2010 telah sebanyak 942 jiwa.

Perkembangan jumlah nelayan di Kawasan Pelabuhan Perikanan Pulau Baai, Kota Bengkulu sebagai unsur yang menunjang suksesnya pembangunan perikanan, memang sangat menggembirakan yaitu nelayan lokal meningkat menjadi 942 jiwa (2010). Pertumbuhan nelayan andon lebih besar dari pertumbuhan nelayan lokal sebesar $12,10 \%$ tahun, menunjukkan bahwa Kawasan Pelabuhan Perikanan Pulau Baai, Kota Bengkulu memiliki daya tarik atau prospektif dibandingkan daerah lainnya. 


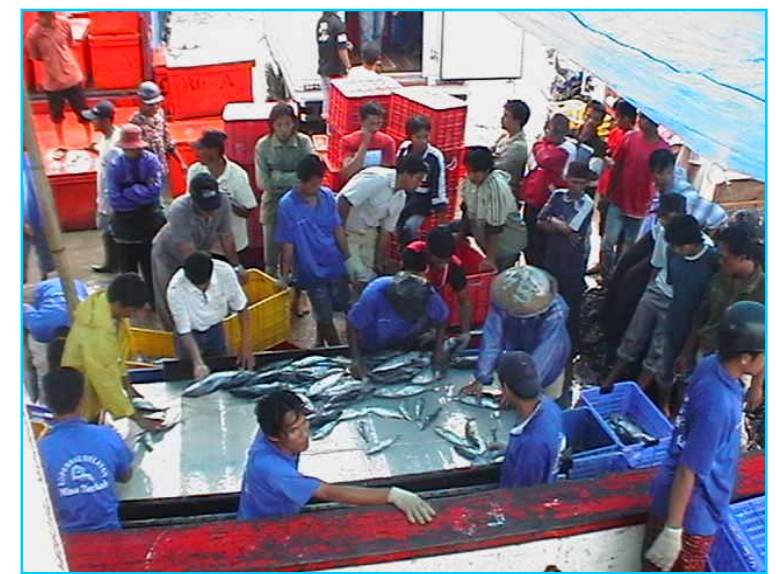

Nelayan membongkar hasil tangkapannya di PPI Pulau Baai

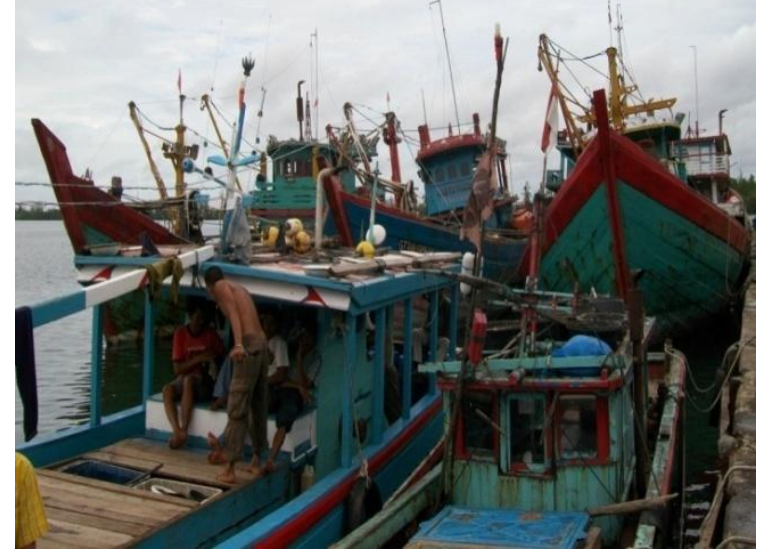

Nelayan di kapalnya yang berlabuh di PPI Pulau Baai

\section{PEMBAHASAN}

\section{A. Kebijakan Pembangunan PPI}

Dari apa yang disampaikan oleh Kepala Bidang Pengelolaan Sumberdaya Kelautan Dinas Kelautan dan Perikanan Propinsi Bengkulu, alasan dasar kenapa pentingnya PPI Pulai Baai untuk ditingkatkan statusnya menjadi PPP karena masih tingginya potensi perikanan tangkap yang ada di samudera Hindia. Namun tingginya potensi perikanan tangkap tersebut tidak didukung dengan fasiltas pelabuhan yang baik dan memadai. Dermaga, kolam labuh, maupun tanggul penahan gelombang yang ada masih tidak memadai, sehingga berakibat kurang maksimalnya pemanfaatan sumberdaya perikanan tangkap yang ada. Oleh karena itu perlu adanya peningkatan status dari PPI menjadi PPP Pulai Baai Bengkulu.

Dalam kebijakan penetapan pembangunan dan peningkatan status yang sebelumnya adalah PPI Pulai Baai yang kemudian menjadi PPP Pulau Baai, Menteri Kelautan dan Perikanan mengeluarkan KEPMEN Kelautan dan Perikanan Nomor 48 tahun 2007 tentang Peningkatan Status Peningkatan PPI Menjadi PPP. Kemudian, PPP Pulau Baai dalam melaksanakan tugas teknis tertentu di bidang pengelolaan pelabuhan perikanan pantai, pengawasan penangkapan ikan dan pelayanan teknis kapal perikanan dijalankan oleh UPPPP Pulau Baai. UPPP Pulau Baai adalah Unit Pelaksana Teknis (UPT) Dinas Perikanan dan Kelautan Provinsi Bengkulu yang berada di PPP Pulau Baai Bengkulu.

Semuanya telah diatur dalam Keputusan Kepala Dinas Perikanan dan Kelautan Provinsi Bengkulu tentang Pembentukan Organisasi Unit Pengelola Pelabuhan Perikanan Pantai Pulau Baai Kota Bengkulu. 


\section{B. Dampak Kehidupan Sosial Masyarakat Peisisir Sekitar}

Dampak perubahan yang akan terjadi pada masyarakat pesisir dan sekitar di Kelurahan Sumber Jaya Kecamatan Kampung Melayu Kota Bengkulu , merupakan suatu gejala wajar jika dilihat dari arti pembangunan yang merupakan usaha sadar, terencana dan terus menerus yang dilakukan oleh suatu bangsa, negara, dan pemerintah menuju modernitas untuk memperbaiki kualitas hidup masyarakat melalui pemanfaatan yang dimiliki.

Perubahan presepsi pada masyarakat khususnya masyarakat pesisir sekitar PPP Pulau Baai akan terjadi apabila terdapat perbedaan pandangan masyarakat terhadap adanya PPP Pulau Baai dan perubahan pandangan tersebut dapat mengarah pada arah yang positif atau negatif. Dari hasil penelitian dengan menggunakan metode wawancara terhadap masyarakat pesisir sekitar PPP Pulau Baai, maka diperoleh data yang menyatakan bahwa terjadi perubahan presepsi yang mengarah pada arah positif.

Masyarakat pesisir sekitar PPP Pulau Baai optimis akan mengalami perubahan kearah yang baik dengan adanya peningkatan PPI Pulau Baai. Dikarenakan masyarakat kelurahan Sumber Jaya sendiri akan merasakan ada perubahan pada daerahnya yang dulunya sepi sekarang menjadi lebih ramai. Selain itu menurut masyarakat kelurahan Sumber Jaya sendiri yang berprofesi sebagai nelayan, adanya peningkatan pembangunan PPI Pulau Baai diharapkan akan mempermudah nelayan dalam melakukan aktifitas sebelum ataupun sesudah melaut dibandingkan dulu sebelum adanya peningkatan pembangunan PPI Pulau Baai yang mana nelayan harus mengeluarkan tenaga ataupun biaya lebih.

Sedangkan perubahan interaksi sosial yang akan terjadi di masyarakat pesisir sekitar dengan adanya pembangunan dan peningkatan status PPI Pulau Baai yang akan mengakibatkan banyaknya masyarakat dari luar wilayah pesisir Kelurahan Sumber Jaya yang datang baik dalam tujuan jual beli maupun seperti nelayan andon akan mempengaruhi interkasi sosial masyarakat pesisir sekitar. Dalam hal ini perubahannya akan mengarah pada segi positif dan juga negatif.

\section{Dampak Kehidupan Ekonomi Masyarakat Pesisir Sekitar}

Pengembangan dan peningkatan status PPI Pulau Baai akan memberikan kesempatan kerja khususnya bagi masyarakat pesisir sekitar Kelurahan Sumnber Jaya. Berdasarkan data primier dan sekunder yang diperoleh selama melakukan penelitian, diketahui bahwa masyarakat pesisir sekitar PPI Pulau Baai akan dapat membuka berbagai usaha. Melalui kebijakan Pemerintah Daerah yang dibantu oleh Pemerintah Provinsi maupun Pemerintah Pusat, memberikan kesempatan pada masyarakat untuk membuka berbagai macam usaha yang secara tidak langsung juga memberikan kesempatan berwirausaha bagi masyarakat sekitar lokasi PPI Pulau Baai. Bentuk usaha yang akan dilakukan masyarakat di lokasi PPI Pulau Baai yaitu antara lain berupa rumah makan/warung makan , cafe, kios , pemondokan dan lain-lain.

Dari berbagai macam usaha tersebut di atas, diharapkan akan menyerap sejumlah tenaga warga sekitar. Mulai dari suami atau istri, anak, saudara, bahkan tetangga dari pemilik usaha yang merupakan penduduk Kelurahan Sumber Jaya setempat. Penyerapan tenaga kerja bisa juga pada sektor jasa. Dari hasil usaha-usaha tersebut juga diharapkan akan memberikan dampak ekonomi yang positif yaitu meningkatkan pendapatan bagi masyarakat sekitar Kelurahan Sumber Jaya tersebut.

\section{KESIMPULAN}

Kebijakan pembangunan dan peningkatan status PPI Pulau Baai di Kelurahan Sumber Jaya Kota Bengkulu , ditingkatkan statusnya melalui Keputusan Menteri Kelautan dan Perikanan Republik Indonesia Nomor 32/PERMEN-KP/2014 tentang Peningkatan Status 
As ad, Program Pengelolaan Pesisir dan PPK Kegiatan DED Peningkatan Status PPI Pulau Baai Provinsi Bengkulu

Pangkalan Pendaratan Ikan (PPI) Pulau Baai Kota Bengkulu menjadi Pelabuhan Perikanan Pantai (PPP). Pembangunan dan peningkatan status PPP Pulau Baai kota Bengkulu ditujukan untuk memberikan fasilitas yang memadai dan sesuai dengan standar kelas pelabuhan perikanan pantai bagi masyarakat nelayan kota Bengkulu. Pengelola teknis PPP diserahkan kepada UPPPP Pulau Baai kota Bengkulu agar mempermudah pengawasan serta pengendalian dari Dinas Kelautan dan Perikanan Provinsi Bengkulu..

Namun dalam pelaksanaannya nanti kebijakan tersebut secara tidak langsung akan mendorong terjadinya perubahan sosial dan ekonomi pada masyarakat pesisir sekitar, khususnya pada masyarakat Kelurahan Sumber Jaya Kecamatan Kampung Melayu Kota Bengkulu.

Dengan peningkatan pembangunan PPI tersebut akan dapat dilihat dari perubahan persepsi masyarakat Kelurahan Sumber Jaya sehingga nantinya akan memberikan perubahan kondisi lingkungan yang lebih ramai dibandingkan dulunya. Dari segi fisik bangunan juga tidak lepas dari penilaian nelayan yang merasa bahwa dengan adanya peningkatan pembangunan PPIdiharapkan akan mempermudah nelayan untuk melakukan kegiatan perikanan. Selain perubahan persepsi, juga akan terjadi perubahan interaksi sosial baik di lokasi PPI Pulau Baai maupun di lingkungan perkampungan masyarakat Kelurahan Sumber Jaya Kecamatan Kampung Melayu Kota Bengkulu.

Perubahan interaksi sosial yang akan dialami oleh masyarakat Kelurahan Sumber Jaya terjadi dikarenakan adanya pedagang ikan yang datang dari luar desa atau bahkan dari luar kota Bengkulu yang datang ke PPI Pulau Baai untuk membeli ikan dari pengepul. Selain itu perubahan interaksi sosial yang terjadi di tengah-tengah lingkungan masyarakat Kelurahan Sumber Jaya adalah terjadinya konflik antara warga Kelurahan Sumber Jaya dengan nelayan andon yang datang dari luar kota bahkan luar pulau. Sedangkan dari segi ekonomi, perubahan tersebut akan dapat dilihat dari jumlah penyerapan tenaga kerja yang terjadi di sekitar lokasi PPI Pulau Baai kota Bengkulu.

\section{REFERENSI}

Abdul Halim,2004, Bunga Rampai: Manajemen Keuangan Daerah, edisi Revisi, Unit Penerbit dan Percetakan (UPP) AMP YKPN, Yogyakarta,

Bachrawi sanusi, 2004, Pengantar Ekonomi Pembangunan, cetakan Pertama, PT Rineka Cipta,

George A. Steiner dan John B. Miner,1997, Management Policy and Strategy, Alih Bahasa Ticoalu dan Agus Dharma, Kebijakan dan Strategi Manajemen, edisi Kedua, Erlangga, Jakarta.

M. Arie Mooduto,2012, Ekonomi Islam: Pilihan Mutlak Seorang Mukmin, Dewan Pimpinan Pusat (DPP) Ikatan Ahli ekonomi Indonesia (IAEI), Jakarta, 2012.

Michael P. Todaro, 2005, Ekonomi untuk Negara Berkembang: Suatu Pengantar Tentang Prinsip-Prinsip, Masalah dan Kebijakan Pembangunan, cetakan Pertama, Bumi Aksara, Jakarta

Suryana, 2000, Ekonomi Pembangunan: Problematika dan Pendekatan, edisi Pertama, Salemba Empat, Jakarta,

Tim Penyusun Kamus Pusat Bahasa, 2002, Kamus Besar Bahasa Indonesia, edisi Ketiga, Balai Pustaka, Jakarta.

Wiryohandoyo, Sudarno. 2002. Perubahan Sosial. Yogyakarta: PT Tiara Wacana Yogya.

Wahab, Solichin Abdul. 2014. Analisis Kebijakan Dari Formulasi Ke Penyusunan Model Model Implementasi Kebijakan Publik. Jakarta : PT Bumi Aksara

Wulansari, Dewi. 2009 Sosiologi Konsep Dan Teori. Bandung: PT Refika Aditama. 